\title{
Effect of Boiling on the Antioxidant Capacity of Dioscorea alata (Raja Ala) Grown in Sri Lanka
}

\author{
Ranithri Abeynayake* and R. Sivakanesan ${ }^{1}$ \\ Postgraduate Institute of Agriculture \\ University of Peradeniya \\ Sri Lanka
}

\begin{abstract}
The present study evaluated the effect of boiling on the antioxidant capacity of Dioscorea alata (raja ala) using water extracts; raw yam extract, boiled yam extract prepared with water used in boiling, boiled yam extract prepared with fresh water. The total antioxidant capacity was measured by ferric reducing antioxidant power (FRAP), 2,2-diphenyl-1-picrylhydrazyl (DPPH) radical scavenging and reducing power assays. The total phenol, total flavonoid, monomeric anthocyanin and condensed tannin contents were measured by Folin-Ciocalteu, aluminium chloride, $p H$ differential and vanillin assays respectively. The results indicated that FRAP, reducing power, total phenol and monomeric anthocyanin contents of the boiled yam extract prepared with fresh water were significantly lower $(p<0.05)$ than that of the other treatments. The DPPH radical scavenging capacity, total flavonoid and condensed tannin contents of the boiled yam extract prepared with fresh water were significantly lower $(p<0.05)$ than that of the raw yam extract. The discarding of water used for boiling the yam has resulted in significant $(p<0.05)$ loss of antioxidants due to loss of water soluble antioxidant compounds. Hence, processing of yam with minimal water and without discarding it can be recommended to get the maximum benefit. Total phenol, total flavonoid and condensed tannin were the major antioxidants found in raw and boiled yam extracts while the monomeric anthocyanin was only a minor antioxidant.
\end{abstract}

Keywords: Antioxidant capacity, boiled yam, Dioscorea alata (raja ala), raw yam

\section{INTRODUCTION}

Emerging research evidences regarding the impact of diet on human health beyond the basic nutrition has led to the curiosity among consumers. In particular, antioxidants are believed to provide a number of health benefits such as, cancer prevention, cardio protection and enhancement of neurological function (Potter, 1997). An antioxidant is a molecule that inhibits the oxidation of other molecules. The mode of action of these compounds in disease prevention is believed to be suppression of oxidative stress. The antioxidant properties of phenols have been confirmed to be more powerful than that of carotenoids, vitamins $\mathrm{C}$ and $\mathrm{E}$ (Rice-Evans et al., 1995).

\footnotetext{
1 Department of Biochemistry, Faculty of Medicine, University of Peradeniya, Sri Lanka

* Corresponding author: aranithri@gmail.com
} 
The edible tubers of genus Dioscorea are consumed in Sri Lanka as a source of energy for long time. Apart from the food value, D. alata (raja ala) cultivars were found to have health benefits such as immune stimulation (Shang et al., 2007) and antihypertensive effects (Liu et al., 2009). Furthermore, Dioscorea yams are highly economical in terms of mass scale cultivation due to the ability to tolerate adverse environmental conditions and requirement of minimum amount of agricultural inputs. Raja ala is one of the most popular D. alata cultivars in Sri Lanka.

Although the antioxidant capacity of raw yams of $D$. alata (raja ala) was determined (Narkhede et al., 2013), no work has been reported about the effect of boiling on the antioxidant capacity. In this context, the objective of this study was to analyse the effect of boiling on antioxidant activity of $D$. alata (raja ala) yams. The result of this work is therefore expected to bring about significant economical and health benefits.

\section{MATERIALS AND METHODS}

\section{Chemicals and instruments}

Acetic acid, sodium acetate, 2,4,6-tripyridyl-s-triazine (TPTZ), ferric chloride hexa-hydrate, ferrous sulphate, 2,2-diphenyl-1-picrylhydrazyl (DPPH), methanol, sodium phosphate, potassium ferricyanide, trichloroacetic acid, Folin-Ciocalteu's phenol reagent, gallic acid, tannic acid, anhydrous sodium carbonate, aluminium chloride, catechin, sodium hydroxide, sodium nitrite, potassium chloride, vanillin, hydrochloric acid were obtained from Sigma chemicals company (MO,USA). All the chemicals were of analytical grade and distilled water was used throughout. Absorbance was measured with uv-vis spectrophotometer (UV 1800, Shimadzu, Japan), centrifugation was done using a centrifuge (MSE, UK) and a digital weighing scale (PA 313, Ohaus, USA) was used in weighing operations.

\section{Collection of plant materials}

Randomly selected mature tubers (nine months maturity) of Dioscorea alata (Raja ala) were collected from the field of Horticultural Crops Research and Development Institute, Gannoruwa, Sri Lanka on March 2014 and those were authenticated by Root and Tuber Crops Division, Horticultural Crops Research and Development Institute, Gannoruwa, Sri Lanka.

\section{Sample preparation and extraction}

Six yams of $D$. alata (raja ala) were randomly selected and cleaned in the laboratory. Flesh was obtained from the core of each sample for analysis. Chemical analysis was done for the extracts of raw and boiled yam samples. The raw yam extract was prepared using $2 \mathrm{~g}$ of macerated yam which was extracted with $20 \mathrm{~mL}$ of distilled water for 5 minutes (treatment A). The boiled yam extracts were prepared by two different methods. In the first method, a yam chunk of $2 \mathrm{~g}$ was boiled for 20 minutes with $20 \mathrm{~mL}$ of distilled water. The boiled yam chunk was macerated and extracted for 5 minutes with water used in boiling (treatment B). In preparation of boiled yam extract according to the second method, a yam chunk of $2 \mathrm{~g}$ was boiled for 20 minutes with $20 \mathrm{~mL}$ of distilled water. Then the water used for boiling was drained off. In the next step, the boiled yam chunk was macerated and extracted for 5 minutes with $20 \mathrm{~mL}$ of fresh distilled water (treatment C). Yam extracts were centrifuged at $4000 \mathrm{rpm}$ for 15 minutes and the supernatants were collected for analysis. 


\section{Estimation of Ferric Reducing Antioxidant Power (FRAP)}

The FRAP assay was done according to the procedure described by Benzie and Strain (1996). The FRAP reagent was prepared by mixing $1 \mathrm{~mL}$ of $(10 \mathrm{mmol} / \mathrm{L}) \mathrm{TPTZ}$ solution in $40 \mathrm{mmol} / \mathrm{L} \mathrm{HCl}, 1 \mathrm{~mL}$ of $\mathrm{FeCl}_{3}(20 \mathrm{mmol} / \mathrm{L})$ and $10 \mathrm{~mL}$ of acetate buffer, $(0.3 \mathrm{~mol} / \mathrm{L}$, $\mathrm{pH}=3.6$ ). Twenty microlitres of $0.1 \mathrm{~g} / \mathrm{mL}$ sample was mixed with $1 \mathrm{~mL}$ of FRAP reagent and the absorbance was measured at $593 \mathrm{~nm}$ after incubating at $28{ }^{\circ} \mathrm{C} \pm 2$ for 4 minutes, against the FRAP reagent as the blank. The absorbance of $1000 \mu \mathrm{M} \mathrm{FeSO} 4$ standard was also measured following the same procedure as for the samples. The ferric reducing antioxidant power was expressed as $\mathrm{FeSO}_{4}$ equivalents $(\mu \mathrm{mol} / \mathrm{g}$ fresh weight $(\mathrm{FW})$ ).

\section{Estimation of reducing power}

The method described by Oyaizu (1986) was used. In brief, $1 \mathrm{~mL}$ of different concentrations $(10,20,30,40 \mathrm{mg} / \mathrm{L})$ of the extract was mixed with $1 \mathrm{~mL}$ of $1 \%$ potassium ferricyanide and $1 \mathrm{~mL}$ of $0.3 \mathrm{M}$ phosphate buffer ( $\mathrm{pH} 6.6$ ). The mixture was incubated at $50{ }^{\circ} \mathrm{C}$ for $20 \mathrm{~min}$. After that $1 \mathrm{~mL}$ of $10 \%$ TCA was added to the mixture. Two millilitres of the above mixture was mixed with $2 \mathrm{~mL}$ of distilled water and $0.4 \mathrm{~mL}$ of $0.1 \% \mathrm{FeCl}_{3}$. The absorbance was measured at $700 \mathrm{~nm}$ after 30 minutes of incubation at $28^{\circ} \mathrm{C} \pm 2$ against distilled water blank. The absorbance at different concentrations was plotted in a graph and the $\mathrm{EC}_{50}$ value which is the respective concentration for 0.5 absorbance was obtained from the graph.

\section{Estimation of DPPH radical scavenging activity}

The free radical scavenging activity of yam extracts was evaluated by DPPH assay according to the method described by Blois (1958). A solution of $0.1 \mathrm{mM}$ solution of DPPH in methanol was prepared and $250 \mu \mathrm{L}$ of this solution was added to $1 \mathrm{~mL}$ of $4,8,12,16,20 \mathrm{mg}$ $\mathrm{FW} / \mathrm{mL}$ yam extracts. The mixture was allowed to stand at $28{ }^{\circ} \mathrm{C} \pm 2$ for 30 minutes and the absorbance was measured at $517 \mathrm{~nm}$. In order to measure the absorbance of the control, 250 $\mu \mathrm{L}$ of DPPH was mixed with $1 \mathrm{~mL}$ of distilled water and the absorbance was taken as in the case of samples. The \% inhibitions were plotted against the respective sample concentrations and the $\mathrm{IC}_{50}$ value which is the respective concentration for $50 \%$ inhibition was found from the graph.

\section{Estimation of total phenolic content}

The total phenolic content was determined by the procedure reported by Singleton and Rossi (1965). About $50 \mu \mathrm{L}$ of $0.1 \mathrm{~g} / \mathrm{L}$ sample and $0.5 \mathrm{~mL}$ of $10 \%$ Folin-Ciocalteu reagent were mixed and allowed to incubate for 3 minutes at $28{ }^{\circ} \mathrm{C} \pm 2$. After that $0.4 \mathrm{~mL}$ of $7.5 \%$ sodium carbonate was added. After 30 minutes of incubation at $28{ }^{\circ} \mathrm{C} \pm 2$, absorbance at $765 \mathrm{~nm}$ was measured against distilled water blank. The standards used were $0.1 \mathrm{~g} / \mathrm{L}$ tannic acid and 0.1 $\mathrm{g} / \mathrm{L}$ gallic acid. The total phenolic concentration was calculated in gallic acid equivalents (mg GAE/g FW) and tannic acid equivalents (mg TAE/g FW).

\section{Estimation of total flavonoid content}

The total flavonoid content was determined using a colorimetric method described by Enujiugha, 2010. Briefly, $250 \mu \mathrm{L}$ of $0.1 \mathrm{~g} / \mathrm{L}$ yam extract was mixed with $1.25 \mathrm{~mL}$ of distilled water, followed by $75 \mu \mathrm{L}$ of $50 \% \mathrm{NaNO}_{2}$ solution. After 6 minutes of incubation at $28{ }^{\circ} \mathrm{C} \pm 2$, $150 \mu \mathrm{L}$ of $10 \% \mathrm{AlCl}_{3} .6 \mathrm{H}_{2} \mathrm{O}$ solution was added and allowed to stand for 5 minutes at 28 ${ }^{\circ} \mathrm{C} \pm 2$ prior to addition of $0.5 \mathrm{~mL}$ of $1 \mathrm{M} \mathrm{NaOH}$. The mixture was brought to $2.5 \mathrm{~mL}$ with 
distilled water. The absorbance was measured immediately against the distilled water blank at $510 \mathrm{~nm}$. The standards used were $0.1 \mathrm{~g} / \mathrm{L}$ catechin and $1 \mathrm{~g} / \mathrm{L}$ tannic acid. The results were calculated in catechin equivalents (mg CAE/g FW) and tannic acid equivalents (mg TAE/g FW).

\section{Estimation of monomeric anthocyanin content}

The monomeric anthocyanin content was estimated by the $\mathrm{pH}$ differential method (Lee et al., $2005)$ using potassium chloride buffer, $\mathrm{pH} 1.0(0.0025 \mathrm{M})$ and sodium acetate buffer, $\mathrm{pH} 4.5$ $(0.4 \mathrm{M})$. Briefly, $1 \mathrm{~mL}$ of $0.1 \mathrm{~g} / \mathrm{L}$ of yam extract was mixed in $4 \mathrm{~mL}$ of corresponding buffer solutions (5 times dilution) and absorbance was measured at 520 and $700 \mathrm{~nm}$. Anthocyanin concentration was calculated and expressed as cyanidin-3-glycoside equivalent (mg/g FW).

\section{Estimation of condensed tannin content}

Analysis of condensed tannin content was carried out according to the method of Broadhurst and Jones (1978). About $1.5 \mathrm{~mL}$ of vanillin in $4 \%$ methanol and $0.75 \mathrm{~mL}$ of concentrated hydrochloric acid were added to $100 \mu \mathrm{L}$ of sample. The mixture was allowed to stand for 15 min at $28^{\circ} \mathrm{C} \pm 2$ and the absorbance was measured at $500 \mathrm{~nm}$ against distilled water blank. The standard was $1 \mathrm{~g} / \mathrm{L}$ catechin. The amount of condensed tannin was calculated in catechin equivalents (mg CAE/g FW).

\section{Statistical analysis}

Five yams were analysed in duplicates and the mean values, standard deviations (SD) and correlation values $\left(\mathrm{r}^{2}\right)$ were calculated. Statistical analysis was conducted on data using ANOVA, the general linear model, with SAS System version 9.1 for Windows. Mean separations were examined using t-test. The differences were considered significant at $\mathrm{p}<$ 0.05 .

\section{RESULTS AND DISCUSSION}

\section{Ferric Reducing Antioxidant Power}

As given in the Table 1, treatment A had the highest total antioxidant capacity (TAC) of $5.83 \pm 0.93 \mu \mathrm{mol} / \mathrm{g}$ FW. The boiled yam extract prepared with the water used for boiling had lesser TAC $(5.17 \pm 0.74 \mu \mathrm{mol} / \mathrm{g} \mathrm{FW})$ which was not significantly different to that of the raw yam. The TAC of $3.89 \pm 0.86 \mu \mathrm{mol} / \mathrm{g} \mathrm{FW}$ in boiled yam extract prepared with fresh water was significantly lower $(\mathrm{p}<0.05)$ compared to treatment A and B. This indicates leaching of water soluble antioxidants during boiling into the medium.

Although, a number of studies reported the TAC of raw yams of Dioscoreae, the effect of boiling has not been reported. According to Narkhede et al. (2013) the TAC of the water extract of raw yams of D. alata was $4.6 \pm 0.06 \mu \mathrm{mol} / \mathrm{g}$ dry weight (DW). However, the value reported for ethanol extract was $12 \pm 0.04 \mu \mathrm{mol} / \mathrm{g}$ of DW. This difference suggests that ethanol is effective in extraction of antioxidants than water. 


\section{DPPH radical scavenging activity}

According to the results shown in the Table 1 , the $\mathrm{IC}_{50}$ values of treatments $\mathrm{A}, \mathrm{B}$ and $\mathrm{C}$ were $18.62 \pm 3.82,20.71 \pm 3.03$ and $24.91 \pm 2.91 \mathrm{mg} \mathrm{FW} / \mathrm{mL}$ respectively. As the lowest $\mathrm{IC}_{50}$ value corresponds to the highest antioxidant activity, treatment A contained significantly higher ( $\mathrm{p}$ $<0.05$ ) antioxidant activity than treatment $\mathrm{C}$. This could be due to destruction of some antioxidants upon boiling and due to leaching of water soluble antioxidants into boiling water.

However, the reported $\mathrm{IC}_{50}$ value $(70.6 \pm 0.72 \mu \mathrm{g} \mathrm{DW} / \mathrm{mL})$ was considerably lower than our value (Narkhede et al., 2013). The considerable discrepancy could be due to use of dry yam powder.

\section{Reducing power}

As shown in the Table 1, raw yam extract reported the lowest $\mathrm{EC}_{50}$ value of $30.71 \pm 7.04 \mathrm{mg}$ $\mathrm{FW} / \mathrm{mL}$ which indicates the highest reducing power. This was followed by the reducing power of treatment $\mathrm{B}(36.89 \pm 10.48 \mathrm{mg} \mathrm{FW} / \mathrm{mL})$. The reducing power of the treatment $\mathrm{C}$ $(50.86 \pm 8.64 \mathrm{mg} \mathrm{FW} / \mathrm{mL})$ was significantly lower $(\mathrm{p}<0.05)$ compared to the other two treatments. This could be due to removal of water soluble antioxidants when discarding the boiled water.

The $\mathrm{EC}_{50}$ values for methanol extracts of steamed yam flour at $100{ }^{\circ} \mathrm{C}$ for 30 minutes of five D. alata cultivars; Daking, Kimabajo, Rapang-rapang, Sampero, and Shiket ranged from $6.2 \pm 0.6$ to $26.3 \pm 3.2 \mathrm{mg} \mathrm{FW} / \mathrm{mL}$ (Cornago et al., 2011). Use of methanol as the solvent, application of different sample preparation method and cultivar wise differences could be the reasons for the higher reducing power compared to the present study.

Table 1. Total antioxidant capacities of yam extracts as measured by ferric reducing antioxidant power, DPPH radical scavenging capacity and reducing power

\begin{tabular}{lccc}
\hline Treatment & $\begin{array}{c}\text { FRAP } \\
(\mu \mathrm{mol} / \mathrm{g} \mathrm{FW})\end{array}$ & $\begin{array}{c}\text { DPPH } \\
\left(\mathrm{IC}_{50}, \mathrm{mg} \mathrm{FW} / \mathrm{mL}\right)\end{array}$ & $\begin{array}{c}\text { Reducing power } \\
\left(\mathrm{EC}_{50}, \mathrm{mg} \mathrm{FW} / \mathrm{mL}\right)\end{array}$ \\
\hline Raw yam extract (A) & $5.83 \pm 0.93^{\mathrm{a}}$ & $18.62 \pm 3.82^{\mathrm{b}}$ & $30.71 \pm 7.04^{\mathrm{b}}$ \\
$\begin{array}{l}\text { Boiled yam extract prepared with } \\
\text { water used in boiling (B) }\end{array}$ & $5.17 \pm 0.74^{\mathrm{a}}$ & $20.71 \pm 3.03^{\mathrm{ab}}$ & $36.89 \pm 10.48^{\mathrm{b}}$ \\
$\begin{array}{l}\text { Boiled yam extract prepared with } \\
\text { fresh water (C) }\end{array}$ & $3.89 \pm 0.86^{\mathrm{b}}$ & $24.91 \pm 2.91^{\mathrm{a}}$ & $50.86 \pm 8.64^{\mathrm{a}}$ \\
\hline
\end{tabular}

Values are mean \pm standard deviation $(n=5)$

Different superscript letters indicate significant difference at $\mathrm{p}<0.05$

\section{Total phenolic content}

The results are expressed as gallic acid equivalents (mg GAE/g FW) and tannic acid equivalents (mg TAE/g FW) and shown in the Table 2. The highest phenolic content of $0.79 \pm 0.14 \mathrm{mg}$ TAE$/ \mathrm{g} \mathrm{FW}$ or $0.74 \pm 0.13 \mathrm{mg} \mathrm{GAE} / \mathrm{g} \mathrm{FW}$ was observed in treatment A. This was followed by treatment B with $0.66 \pm 0.11 \mathrm{mg}$ TAE$/ \mathrm{g}$ FW or $0.61 \pm 0.10 \mathrm{mg}$ GAE/g FW. 
The lowest phenolic content of $0.49 \pm 0.05 \mathrm{mg}$ TAE$/ \mathrm{g} \mathrm{FW}$ or $0.49 \pm 0.05 \mathrm{mg} \mathrm{GAE} / \mathrm{g}$ FW was obtained for treatment $\mathrm{C}$ which was significantly lower $(\mathrm{p}<0.05)$ than that of the treatment $\mathrm{A}$ and $\mathrm{B}$. This might be due to removal of phenolic compounds when discarding the boiled water.

Table 2. Total phenolic content (TPC) of yam extracts

\begin{tabular}{lcc}
\hline Treatment & \multicolumn{2}{c}{ TPC } \\
\cline { 2 - 3 } Raw yam extract (A) & $0.79 \pm 0.14^{\mathrm{a}}$ & $0.74 \pm 0.13^{\mathrm{a}}$ \\
Boiled yam extract prepared with water used in boiling (B) & $0.66 \pm 0.11^{\mathrm{a}}$ & $0.61 \pm 0.10^{\mathrm{a}}$ \\
Boiled yam extract prepared with fresh water (C) & $0.49 \pm 0.05^{\mathrm{b}}$ & $0.49 \pm 0.05^{\mathrm{b}}$ \\
\hline
\end{tabular}

Values are mean \pm standard deviation $(n=5)$

Superscript letters in each column indicate significant difference at $\mathrm{p}<0.05$

However, for the raw yams of $D$. alata, the reported total phenolic content $(0.89 \pm 0.03 \mathrm{mg}$ GAE/g DW) (Narkhede et al., 2013) was slightly higher than the observed value. This difference could be due to expression of results as FW and DW.

\section{Total flavonoid content}

The results are given in the Table 3 as tannic acid equivalents (mg TAE/g FW) and as catechin equivalents ( $\mathrm{mg} \mathrm{CE} / \mathrm{g} \mathrm{FW})$.

Table 3. Total flavonoid content (TFC) of yam extracts

\begin{tabular}{lcc}
\hline \multirow{2}{*}{ Treatment } & \multicolumn{2}{c}{ TFC } \\
\cline { 2 - 3 } Raw yam extract (A) & $2.22 \pm 0.72^{\mathrm{a}}$ & $0.17 \pm 0.05^{\mathrm{a}}$ \\
Boiled yam extract prepared with water used in boiling ( & $1.47 \pm 0.75^{\mathrm{ab}}$ & $0.11 \pm 0.06^{\mathrm{ab}}$ \\
Boiled yam extract prepared with fresh water $(\mathrm{C})$ & $0.75 \pm 0.32^{\mathrm{b}}$ & $0.06 \pm 0.02^{\mathrm{b}}$ \\
\hline
\end{tabular}

Values are mean \pm standard deviation $(n=5)$

Superscript letters in each column indicate significant difference at $\mathrm{p}<0.05$

The significant difference $(\mathrm{p}<0.05)$ between the total flavonoid contents of the treatment $\mathrm{A}$ $(2.22 \pm 0.72 \mathrm{mg} \mathrm{TAE} / \mathrm{g} \mathrm{FW}$ or $0.17 \pm 0.05 \mathrm{mg} \mathrm{CE} / \mathrm{g} \mathrm{FW})$ and the treatment $\mathrm{C}(0.75 \pm 0.32 \mathrm{mg}$ $\mathrm{TAE} / \mathrm{g} \mathrm{FW}$ or $0.06 \pm 0.02 \mathrm{mg} \mathrm{CE} / \mathrm{g} \mathrm{FW}$ ) could be due destruction of some antioxidant compounds upon boiling and due to leaching of water soluble flavonoids into boiling water. The treatment B had a total flavonoid content of $1.47 \pm 0.75 \mathrm{mg}$ TAE$/ \mathrm{g}$ FW or $0.11 \pm 0.06 \mathrm{mg}$ $\mathrm{CE} / \mathrm{g} \mathrm{FW}$. For the raw yams of $D$. alata, the reported value of total phenol compounds were, $0.14 \pm 0.02 \mathrm{mg}$ QE/g DW (Narkhede et al., 2013), which was similar to the present study when the total flavonoid content was expressed in catechin equivalents. 


\section{Monomeric anthocyanin content}

According to the Table 4, the treatment $\mathrm{B}$ had the highest monomeric anthocyanin content $(0.08 \pm 0.02 \mathrm{mg} / \mathrm{g} \mathrm{FW})$. The monomeric anthocyanin content of the treatment $\mathrm{C}(0.03 \pm 0.01$ $\mathrm{mg} / \mathrm{g} \mathrm{FW})$ was significantly lower than that of the treatments $\mathrm{A}(0.06 \pm 0.02 \mathrm{mg} / \mathrm{g} \mathrm{FW})$ and B. Thus, discarding the boiled water could be the reason for significantly lower $(p<0.05)$ monomeric anthocyanin content of the boiled yam extract prepared with fresh water.

\section{Condensed tannin content}

The condensed tannin content is expressed as catechin equivalents (mg CE/g FW) in the Table 4. The condensed tannin content of the treatment A, B and C were $1.61 \pm 0.59$, $1.21 \pm 0.61$ and $0.65 \pm 0.29 \mathrm{mg} \mathrm{CE} / \mathrm{g} \mathrm{FW}$ respectively. The significant difference $(\mathrm{p}<0.05)$ between the condensed tannin contents of treatment $\mathrm{A}$ and $\mathrm{C}$ could be due to leaching of water soluble condensed tannins into boiling water and due to destruction upon boiling. For raw yams, the reported value was $1.73 \pm 0.06 \mathrm{mg}$ CE/g DW (Narkhede et al., 2013).

Table 4. Monomeric anthocyanin content (MAC) and condensed tannin content (CTC) of yam extracts

\begin{tabular}{llc}
\hline Treatment & \multicolumn{1}{c}{$\begin{array}{c}\text { MAC } \\
(\mathrm{mg} / \mathrm{g} \\
\text { FW) }\end{array}$} & $\begin{array}{c}\text { CTC } \\
(\mathrm{mg} \text { CE/g } \\
\text { FW })\end{array}$ \\
\hline Raw yam extract (A) & $0.06 \pm 0.02^{\mathrm{a}}$ & $1.61 \pm 0.59^{\mathrm{a}}$ \\
Boiled yam extract prepared with water used in boiling ( & $0.08 \pm 0.03^{\mathrm{a}}$ & $1.21 \pm 0.61^{\mathrm{ab}}$ \\
Boiled yam extract prepared with fresh water (C) & $0.03 \pm 0.01^{\mathrm{b}}$ & $0.65 \pm 0.29^{\mathrm{b}}$ \\
\hline
\end{tabular}

Values are mean \pm standard deviation $(n=5)$

Different superscript letters indicate significant difference at $\mathrm{p}<0.05$

Correlation between antioxidant capacities, total flavonoid, total phenol, monomeric anthocyanin and condensed tannin content

The Table 5 compares the correlation $\left(\mathrm{r}^{2}\right)$ between TAC of different treatments and individual antioxidants. In the raw yams, strong correlation between the TAC and total phenolic content indicates that phenolic compounds could be the main components responsible for antioxidant activity. Moreover, a strong correlation between the total phenolic content and total flavonoid as well as the condensed tannin content indicate that the total flavonoid and condensed tannin could be the major polyphenols in treatment A. Also, there was a strong correlation between the total flavonoid and monomeric anthocyanin content, indicating that monomeric anthocyanin could be one of the major flavonoids in treatment A. However, the weak relationship between the TAC and the monomeric anthocyanin suggests that contribution of monomeric anthocyanin to the TAC might be low.

Overall, the TAC measured as FRAP and DPPH radical scavenging capacity showed strong correlation with the total phenol, total flavonoid as well as the condensed tannin content of the boiled yam extract prepared with water used in boiling, indicating the significance of those phenolic compounds contributing to TAC . Anyhow, there was only a weak relationship between reducing power and phenolic compounds. The monomeric anthocyanin 
was not a major antioxidant compound in treatment B due to the weak correlation with TAC. Similar to the treatment A, total phenols showed a strong correlation with the total flavonoid and the condensed tannin content of treatment B suggesting that flavonoids and condensed tannins were the main polyphenol compounds.

In the boiled yam extract prepared with fresh water, total phenol, total flavonoid and condensed tannin compounds had strong relationship with TAC measured by DPPH radical scavenging and reducing power assays, while FRAP had a weak correlation. Therefore, it could be suggested that above phenolic compounds could be the major antioxidants in treatment $\mathrm{C}$. The extremely weak correlation between the TAC and monomeric anthocyanin suggests that monomeric anthocyanin was only a minor antioxidant. The total flavonoids could be the major polyphenol responsible for the TAC as there was a strong correlation with the total phenol content. However, the weak correlation between the total flavonoid and monomeric anthocyanin suggests that monomeric anthocyanin was not the major flavonoid in treatment $\mathrm{C}$. The condensed tannins might not be among the main polyphenols of the treatment $\mathrm{C}$ due to the weak relationship with total phenol content. 
Table 5. Correlation $\left(\mathrm{r}^{2}\right)$ values among the antioxidant capacities of yam extracts

\begin{tabular}{|c|c|c|c|c|c|c|c|}
\hline \multirow{2}{*}{\multicolumn{2}{|c|}{$\begin{array}{c}\text { FRAP } \\
(\mu \mathrm{mol} / \mathbf{g} \mathbf{F W})\end{array}$}} & \multirow{3}{*}{$\begin{array}{l}\mathrm{DPPH} \\
\left(\mathrm{IC}_{\mathbf{5 0}}, \mathbf{m g}\right. \\
\text { FW/mL })\end{array}$} & \multirow{2}{*}{$\begin{array}{l}\text { Reducing } \\
\text { power } \\
\left(\mathbf{E C}_{\mathbf{5 0}}, \mathbf{m g}\right. \\
\mathbf{F W} / \mathbf{m L})\end{array}$} & \multirow{2}{*}{\multicolumn{2}{|c|}{$\begin{array}{l}\text { TPC } \\
\text { (mg TAE/g F'(mg GAE/g FW) }\end{array}$}} & \multicolumn{2}{|l|}{ TFC } \\
\hline & & & & & & \multicolumn{2}{|c|}{$(\mathrm{mg}$ TAE/g FW) (mg CE/g FW) } \\
\hline \multicolumn{7}{|c|}{ Raw yam extract (treatment $\mathrm{A}$ ) } & \\
\hline TPC (mg TAE/g & 0.78 & 0.71 & 0.81 & - & - & - & - \\
\hline TPC (mg GAE/g & 0.87 & 0.77 & 0.88 & - & - & - & - \\
\hline $\mathrm{TFC}(\mathrm{mg} \mathrm{TAE} / \mathrm{g}$ & 0.70 & 0.73 & 0.77 & 0.95 & 0.91 & - & - \\
\hline TFC (mg CE/g & 0.79 & 0.80 & 0.85 & 0.97 & 0.94 & - & - \\
\hline MAC (mg/g FW) & 0.37 & 0.30 & 0.39 & - & - & 0.78 & 0.75 \\
\hline CTC (mg CE/g & 0.63 & 0.55 & 0.65 & 0.88 & 0.87 & - & - \\
\hline \multicolumn{8}{|c|}{ Boiled vam extract prepared with water used in boiling (treatment B) } \\
\hline TPC (mg TAE/g & 0.56 & 0.49 & 0.37 & - & - & - & - \\
\hline TPC (mg GAE/g & 0.67 & 0.61 & 0.48 & - & - & - & - \\
\hline TFC (mg TAE/g & 0.65 & 0.65 & 0.43 & 0.90 & 0.94 & - & - \\
\hline TFC (mg CE/g & 0.67 & 0.68 & 0.46 & 0.86 & 0.91 & - & - \\
\hline $\operatorname{MAC}(\mathrm{mg} / \mathrm{g} \mathrm{FW})$ & 0.42 & 0.42 & 0.32 & - & - & 0.83 & 0.85 \\
\hline CTC (mg CE/g & 0.62 & 0.66 & 0.38 & 0.75 & 0.82 & - & - \\
\hline \multicolumn{8}{|c|}{ Boiled vam extract prepared with fresh water (treatment C) } \\
\hline TPC (mg TAE/g & 0.47 & 0.58 & 0.72 & - & - & - & - \\
\hline TPC (mg GAE/g & 0.61 & 0.77 & 0.77 & - & - & - & - \\
\hline TFC (mg TAE/g & 0.41 & 0.51 & 0.70 & 0.78 & 0.68 & - & - \\
\hline TFC (mg CE/g & 0.49 & 0.57 & 0.74 & 0.70 & 0.77 & - & - \\
\hline $\mathrm{MAC}(\mathrm{mg} / \mathrm{g} \mathrm{FW})$ & 0.002 & 0.002 & 0.04 & - & - & 0.19 & 0.16 \\
\hline CTC (mg CE/g FW) & 0.49 & 0.51 & 0.76 & 0.45 & 0.38 & - & - \\
\hline
\end{tabular}




\section{CONCLUSIONS}

In conclusion, the boiled yam prepared using the fresh water had significantly low antioxidant concentration than the other treatments based on the total phenol, monomeric anthocyanin and the TAC measured by FRAP and reducing power assays. It also had significantly lower DPPH radical scavenging capacity, total flavonoid and condensed tannin content compared to the raw yam extract. The discarding of water used for boiling the yam has resulted in significant loss of antioxidants due to loss of water soluble antioxidant compounds. Hence, processing of yam with minimal water and without discarding it can be recommended to get the maximum benefit. Total phenol, total flavonoid and condensed tannin were the major antioxidants found in raw and boiled yam extracts while the monomeric anthocyanin was only a minor antioxidant.

\section{ACKNOWLEDGMENT}

The authors thank Horticultural Crops Research and Development Institute, Gannoruwa for providing samples for the study.

\section{REFERENCES}

Benzie, I.F.F. and Strain, J.J. (1996). The ferric reducing ability of plasma (FRAP) as a measure of antioxidant power: The FRAP assay. Analytical Biochemistry, 239, 70 - 76.

Blois, M.S. (1958). Antioxidant determination by the use of a stable free radical. Nature, $181,1199-1200$.

Broadhurst, R.B. and Jones, W.T. (1978). Analysis of condensed tannins using acidified vanillin. Journal of the Science of Food and Agriculture, 29, 788 - 794.

Cornago, D.F., Rumbaoa, R.G.O. and Geronimo, I.M. (2011). Philippine yam (Dioscorea spp.) tubers phenolic content and antioxidant capacity. Philippine Journal of Science, 140, $145-152$.

Enujiugha, V.N. (2010), The antioxidant and free radical scavenging capacity of phenolics from African locust bean seeds (Parkia biglobosa). Advances in Food Sciences, 32, 88 - 93.

Lee, J., Durst, R.W. and Wrolstad, R.E. (2005). Determination of total monomeric anthocyanin pigment content of fruit juices, beverages, natural colorants, and wines by the $\mathrm{pH}$ differential method: collaborative study. Journal of AOAC International, 88(5), 1269 1278.

Liu, Y., Lin, Y., Liu, D., Han, C., Chen, C. and Fan, M. (2009). Effects of different types of yam (Dioscorea alata) products on blood pressure of spontaneously hypertensive rats. Bioscience Biotechnology and Biochemistry, 73, 1371 - 1376.

Narkhede, A., Gill, J., Thakur, K., Singh, D., Singh, E., Kulkarni, O., Harsulkar, A. and Jagtap, S. (2013). Total polyphenolic content and free radical quenching potential of Dioscorea alata L. tubers. International Journal of Pharmacy and Pharmaceutical Sciences, $5,866-869$. 
Oyaizu, M. (1986). Studies on product of browning reaction prepared from glucose amine. Japanese Journal of Nutrition, 44, 307 - 315.

Potter, J.D. (1997). Cancer prevention: Epidemiology and experiment. Cancer Letters, 114, 7 $-9$

Rice-Evans, C.A', Miller, N.J., Bolwell, P.G., Bramley, P.M. and Pridham, J.B. (1995). The relative antioxidant activities of plant derived polyphenolic flavonoids. Free Radical Research, 22(4), 375 - 383.

Shang, H.F., Cheng, H.C., Liang, H.J., Liu, H.Y., Liu, S.Y. and Hou, WC. (2007). Immuostimulatory activities of yam tuber mucilages. Botanical Studies, 48, 63 - 70.

Singleton, V.L. and Rossi, J.A. (1965). Colorimetry of total phenolics with phosphomolybdic-phosphotungstic acid reagents. American Journal of Enology Viticulture , $16,144-158$. 